\title{
Threshold Dose of Cytogenetic Toxicity of Lindane, Malathion and Metacid in Allium cepo Root-tip Cells
}

\author{
Dinesh Kumar and S.P. Sinha \\ Department of Zoology, Bhagalpur University, \\ Bhagalpur-812007, India
}

Accepted September 5, 1988

In order to have plenty of cheap food for the ever increasing population, large number of agrochemicals are these days being used. Pesticides are one such chemical which protect the standing as well as stored crops and cereals. Plant-based residues of most of these agrochemicals have been repoted to be genotoxic (Stevans 1971, Amer and Farah 1974, Amer and Farah 1976, Mishra and Sinha 1979, Sinha et al. 1979, Fishbein 1984, Sinha et al, 1984, Sinha 1988).

Under the circumstance, it is being advocated that the use of chemical pesticides be stopped, and some alternative safer method be adopted. As the commerical exploitation of the latter technology is still in its developing phase, the use of chemical pesticides is bound to continue at least for a few more decades. One short-term solution to the problem is to use the pesticides at such dose on which they retain their pesticidal property but have little or no cytotoxic/genotoxic effect. This dose is called as threshold dose, and it can be inferred with confidence from dose-response curves well populated with accurate experimental points at low doses (Kumar and Sinha 1989). The aim of the present work is to determine such threshold dose of a few commonly used pesticides in a well-known test-system.

\section{Material and methods}

Experiments were performed using Malathion (O-O, dimethyl phosphorodithioate of diethyl mercaptosuccinate), Metacid ( $\mathrm{O}-\mathrm{O}$, dimethyl-O, -p nitrophenyl phosphorothioate) and Lindane $(\gamma-1,2,3,4,5,6$-hexachlorocyclohexane). The test-system selected for the purpose is mitotically dividing root-tip cells of onion (Allium cepa).

Onion bulbs (25-30 g) with $48 \mathrm{hrs}$ old roots (grown over tap water) were allowed to grow for another $48 \mathrm{hrs}$ on ten different concentrations of pesticides ranging from 0.1 to $500.0 \mathrm{ppm}$ (because these pesticides are used commercially in the dose-range of 100-2000 ppm depending upon the pest). The roots were then thoroughly washed, fixed in aceto-alcohol and stained with acetocarmine squash method. The mitotic index and the rate of chromosomal abnormalities among the meristematic cells were considered as parameters for evaluating the relative cytotoxicity of the pesticides at various doses. The mitotic-index was expressed in terms of relative division rate (RDR) (Egami and Hyodo-Taguchi 1973):

$$
R D R=\frac{\begin{array}{l}
\% \text { of dividing cells in }-\% \text { of dividing cells in } \\
\text { treated variant }
\end{array}}{100-\% \text { of dividing cells in control variant }} \times 100 .
$$

A similar ratio, the relative abnormality rate (RAR) was also calculated in the same manner.

Desired randomness in counting of the dividing cells was achieved by the method suggested by Bhalla et al. (1973). The control variant of bulbs were all along grown over normal tap water with one change after $24 \mathrm{hrs}$. 


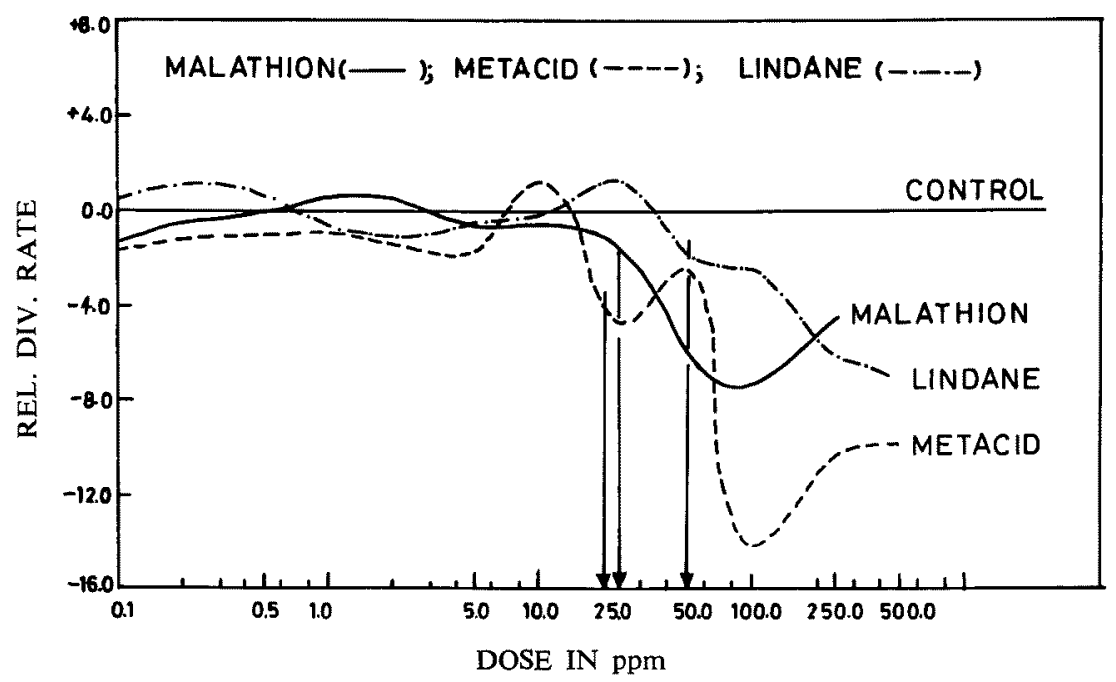

Fig. 1. Relative division rate (RDR) in root-tip cells of onion (Allium cepa) after treatment with different concentrations of malathion, metacid and lindane.

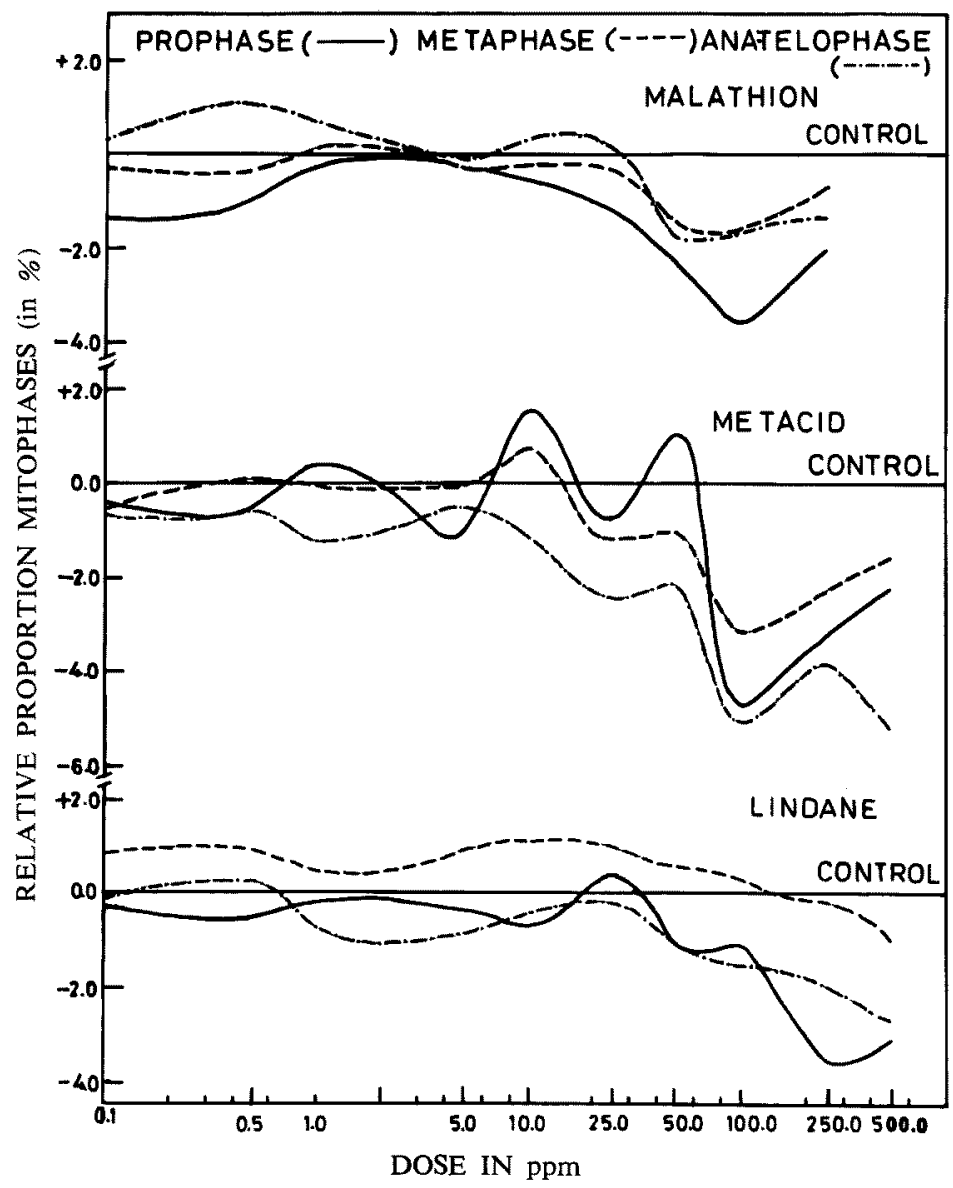

Fig. 2. Relative proportion (\%) of mitophases (RPM) in onion root-tip cells after treatment with three pesticides. 


\section{Results and discussion}

The relative division rate (RDR) and relative abnormality rate (RAR) were plotted as dose-response curves. All the three pesticides could retard the mitotic-index which was significantly so at doses above $25 \mathrm{ppm}$ of Malathion, $20 \mathrm{ppm}$ of Metacid and $50 \mathrm{ppm}$ of Lindane (Fig. 1). Hence these doses may be deemed as threshold dose for the mitoinhibitory effect of the respective pesticides. Phase-wise distribution of dividing cells could indicate (Fig. 2) that the decreased RDR is chiefly due to decrease in prophase population, which may be due to pesticide induced arrest of cells in $G_{0}$ phase or a retardation in the pace of events during ' $S$ ' and/or $G_{2}$ phases. Metaphase and ana-telophase populations were less affected (Fig. 2). (Cummins 1969, Petersen et al. 1969).

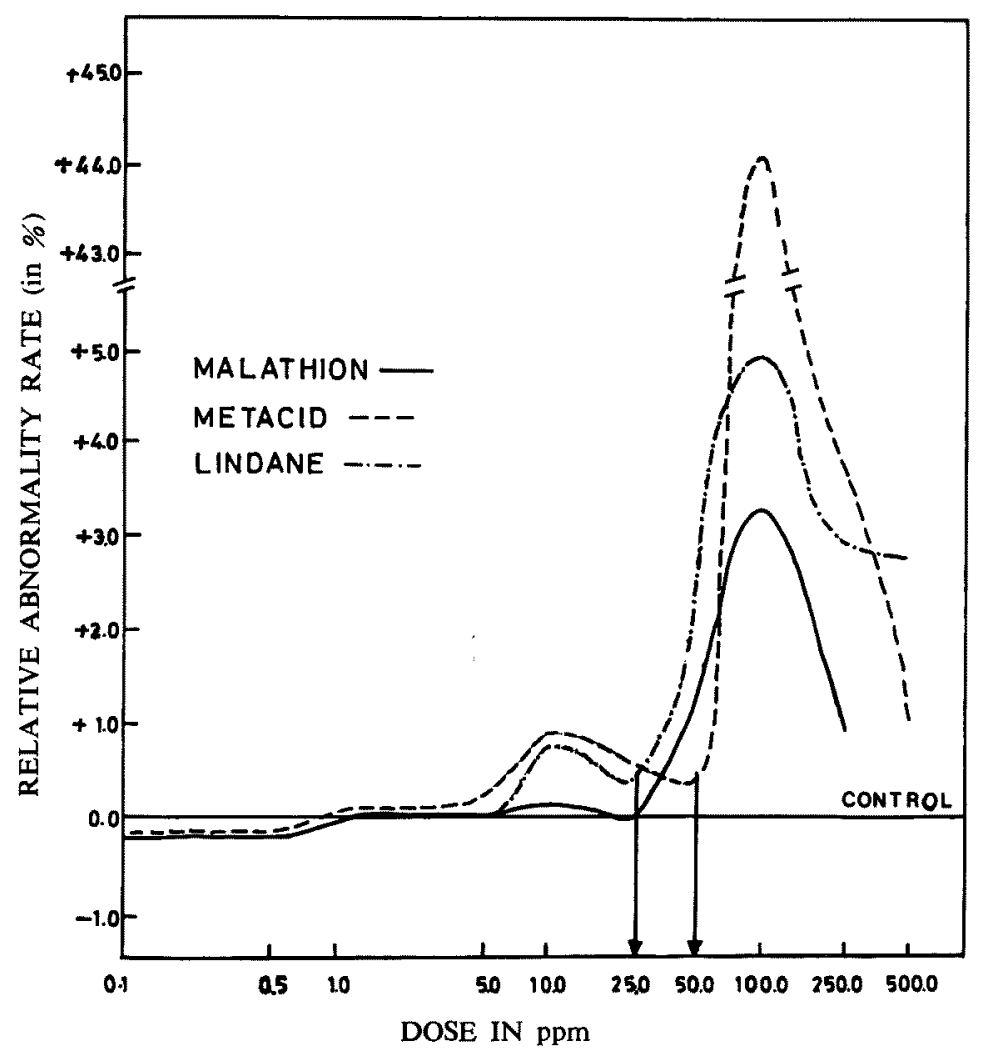

Fig. 3. Relative abnormality rate (RAR) in dividing cells.

The pesticides could also induce abnormalities of both gross (fragmentation, clumping, polyploidy, multipolar spindle, multinucleate cells, disturbed cytokinesis etc.) and individual (anaphase bridge, laggards and chromosome break) nature (Table 1, Fig. 4). The relative abnormality rate (RAR), for both types taken together, appears to increase very sharply after about $25 \mathrm{ppm}$ concentration of Malathion and Lindane, and about $50 \mathrm{ppm}$ in case of Metacid (Fig. 3). These values are thus in close approximation of the threshold dose observed for mitotic inhibition. Decrease in the abnormality rate observed at $100 \mathrm{ppm}$ and concentrations higher than it, is perhaps due to ceasure of mitosis caused by them. The gross type abnormalities were relatively more frequent than the individual ones at almost all the concentrations of the three pesticides. The reason may be that the gross type abnormalities are a conglomerate 


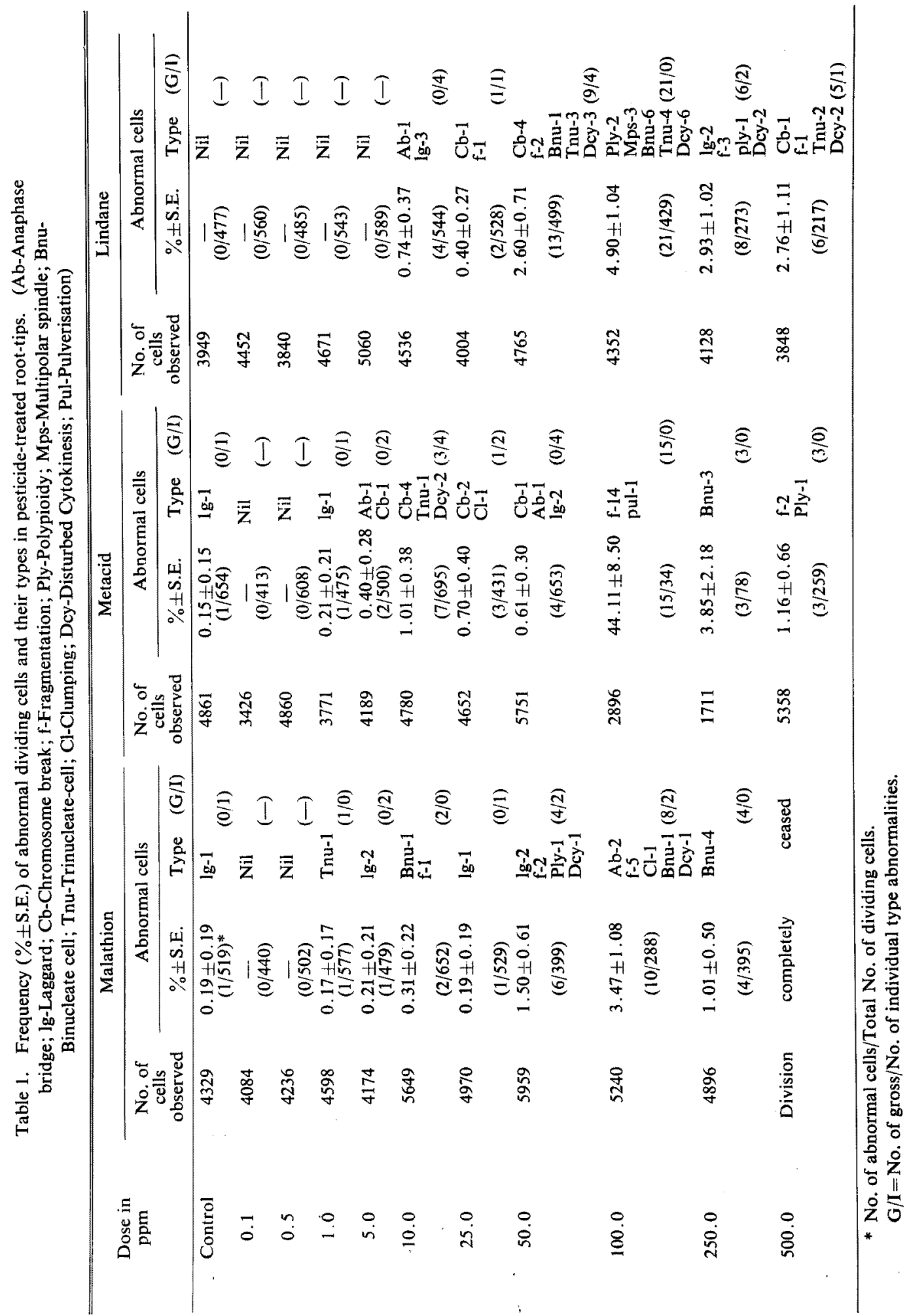



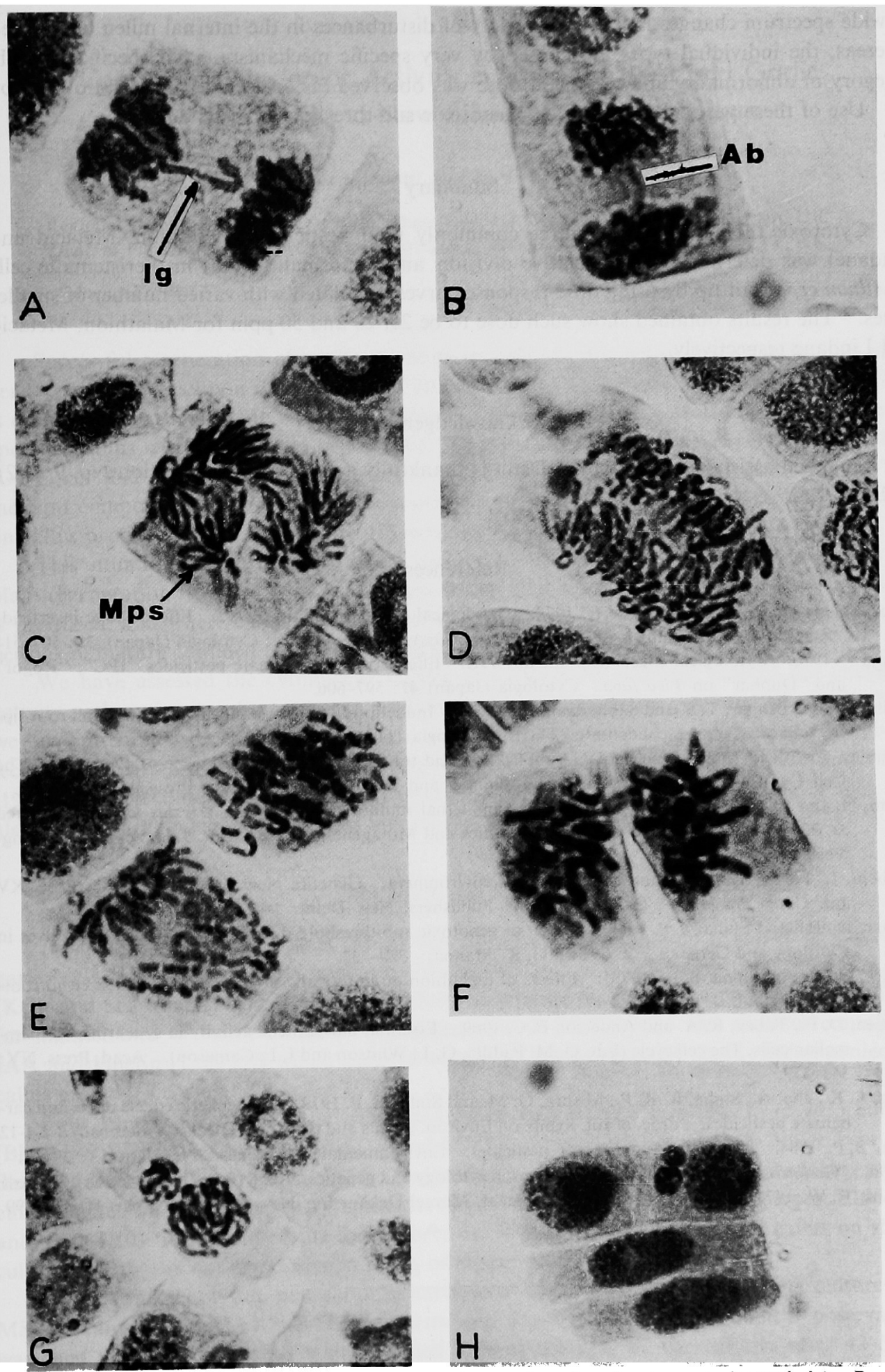

Fig. 4. Chromosomal abnormalities in treated roct-tip cells of onion. A, laggard (lg). B, anaphase bridge $(\mathrm{Ab})$. C, multipolar spindle $(\mathrm{mps})$. D, a polyploid cell in anaphase. E, fragmentation (f). F, arrested cytokinesis with metaphase configuration of chromosomes in daughter cells. $\mathrm{G}, \mathrm{H}$, unequal karyokinesis leading to bi- $(\mathrm{G})$ and trinucleate $(\mathrm{H})$ cells. 
of wide spectrum changes induced by variety of disturbances in the internal mileu of the cell, whereas, the individual types are caused by very specific mechanism. No specificity in the category of abnormality and treatment dose was observed (as exhibited by $\mathrm{G} / \mathrm{I}$ ratio in Table 1). Use of these pesticides at their cytogenotoxic sub-threshold doses is advised.

\section{Summary}

Cytotoxic threshold dose of three commonly used pesticides (Malathion, Metacid and Lindane) was determined using relative division and abnormality rates in meristematic cells of Allium cepa root tip by using dose-response curves populated with varied number of smaller doses. The results obtained show such dose to be 25, 20 and $50 \mathrm{ppm}$ for Malathion, Metacid and Lindane respectively.

\section{Acknowledgement}

Financial assistance from CSIR, Delhi is thankfully acknowledged (Sanction No. 9/24(2)/ 85 EMR-I).

\section{References}

Amer, Soheir M. and Farah, Odette R. 1974. Cytological effects of pesticides VI. Effect of the insecticide "ROGOR" on the mitosis of Vicia faba and Gossypium barbadense; Cytologia (Japan). 39: 507-514

- and - 1976. Cytological effects of pesticides VIII. Effects of the carbamate pesticides "IPC", "Rogor" and "Duphar" on Vica faba. Cytologia (Japan) 41: 597-606.

Bhalla, P. R., Kochhar, T. S. and Sabharwal, P. S. 1973. Induction of mitotic abnormalities in onion root-tips by tobaccco smoke condensate (TSC).; Cytologia (Japan) 38: 707-712.

Cummins, Joseph E. 1969. Nuclear DNA replication and transcription during cell cycle of Physarum. The Cell Cycle Edt. G. M. Padilla, G. L. Whitson and I. L. Cameron. Acad. Press. NY: 141-158.

Egami, N. and Hyodo-Taguchi, Y. 1973. Dominant lethal mutation rates in fish, Oryzias latipes, irradiated at various stages of gametogenesis. Genetics and Mutagenesis of Fish (Edt. J. H. Schröder) SpringVerlag: $75-81$.

Fishbein, L. 1984. Mutagens and carcinogens in environment. Genetics New Frontiers, Vol. 3 (Proc. XV Int. Cong. Genetics). Oxford and IBH Publishers, New Delhi: 3-42.

Kumar, Dinesh and Sinha, S. P. 1989. Search of genotoxic sub-threshold dose of Malathion; Perspectives in Cytology and Genetics Vol. 6 (Edt. G. K. Manna): 729-732.

Mishra, G. M. and Sinha, S. P. (1979): Effects of malathion on mitotically dividng onion (Allium cepa) roottip cells. Ind. J. Expt. Biol. 17: 716-717.

Petersen, D. F., Tobey, R. A. and Anderson E. C. 1969. Essential biosynthetic activity in synchronized mammalian cells, The cell cycle (Edt. O. M. Padilla, G. L. Whitson and I. L. Cameron), Acad. Press. NY: 341-359.

Sinha, A. K., Jha, A., Sinha, R. R. P., Mishra, G. M. and Sinha, S. P. 1979. Cytogenetic effects of certain carbamate pesticides: Proc. of Int. Symp. on Environ. agents and their biol. effects (Hyderabad) S-2-1-12

Sinha, S. P. 1984. Cytogenetic toxicity of pesticides. Environmental Mutagenesis Newsletter 3: 39-42.

- 1988. Genotoxicity of pesticides; Perspectives in cytology and genetics. Vol. 6 (Edt. G. K. Manna), in press.

Stevans, R. W. 1971. Pesticides in the environment. Marcel Dekker Inc. New York Vol. 1 part II: 310-399. 